\title{
SISTEM PANEL SURYA MENGGUNAKAN SYNCHRONOUS BUCK CONVERTER DENGAN TEKNIK MPPT
}

\section{Solar Panel System Using Synchronous Buck Converter With MPPT Techniques}

\author{
Pungky Habib Bachtiar ${ }^{1}$, Triwahju Hardianto ${ }^{2}$, Andi Setiawan ${ }^{2}$, \\ ${ }^{1}$ Jurusan Teknik Elektro, Fakultas Teknik, Universitas Jember \\ 2, Staf Pengajar Jurusan Teknik Elektro, Fakultas Teknik, Universitas Jember \\ Jl. Kalimantan 37, Jember 68121 \\ Email : pungkyhabib@gmail.com ${ }^{1}$, triwahjupustaka@gmail.com², andismt@gmail.com³,
}

\begin{abstract}
ABSTRAK
DC-DC converter adaah bagian penting dari sistem panel surya.. Masalah Rugi daya dari Converter DC-DC step down atau Buck Converter menjadikan tidak maksimal dalam pemanfaatan energi terbarukan. Peper ini membahas rancangan topologi atau sistem kerja dari Buck Converter Konvensional sehingga mampu meningkatkan efisiensi pemanfaatan energi terbarukan. Perbedaan yang mendasar dari Synchronous Buck Converter dengan Buck Converter Konvensional terdapat pada komponen elektronika yang digunakan. Dioda pada konverter dapat mengurangi tegangan dalam keadaan forward bias yaitu +- 0.7 V. Pada Synchronous Buck Converter komponen dioda digantikan dengan MOSFET yang mana akan membuka dan menutup secara bergantian untuk mengatasi masalah tersebut. Untuk memaksimalkan pemanfaatan energi terbarukan, dari penelitian sebelumnya Teknik MPPT dinilai mampu dalam pelacakan titik daya maksimum. Sistem Panel Surya $50 \mathrm{Wp}$ menggunakan Synchronous Buck Converter dengan Teknik MPPT ini telah diuji selama 6 jam pada tanggal 1 Mei 2020 di Laboratorium Sistem Tenaga Teknik Elektro Universitas Jember mulai pukul 08.00 WIB sampai dengan pukul 14.00 WIB. Sistem Tersebut mampu memanen energi total 423611,3807 Joule tersimpan pada baterai VRLA. Total energi keluaran Panel surya selama pengujian yaitu 468845,0587 Joule. Efisiensi sistem ini sebesar $90.35 \%$. Dengan Error persen Volt meter +-0.56 \%, ampere meter +-2.19\%.
\end{abstract}

Kata kunci: Panel Surya, Synchronous Buck Converter, MPPT, VRLA

\section{ABSTRACT}

$D C-D C$ Converter is an important part of the solar panel system. The issue of power loss from the step down DC-DC Converter or Buck Converter causes the use of renewable energy resources is less optimal. This paper discusses the topology or operation of the Conventional Buck Converter to increase the efficiency of renewable energy utilization. The main difference between the Synchronous Buck Converter and the Conventional Buck Converter is in the electronic components used. The diode in the converter can reduce the voltage in the forward bias condition i.e , $+-0.7 \mathrm{~V}$. In the Synchronous Buck Converter, the diode replaced by a MOSFET which is activated alternately to solve this problem. In order to maximize the use of renewable energy, based on the previous research, the MPPT technique is considered capable to track the points for the maximum power. The developed 50 Wp Solar Panel System using Synchronous Buck Converter with MPPT technique has been successfully tested for 6 hours on May 1, 2020 at the Electrical Engineering Power System Laboratory, University of Jember from 08.00 WIB to 14.00 WIB. The system is able to harvest a total of 4,23611,3807 Joules of energy stored in VRLA batteries. The total energy output of the solar panels during the test is 468845.0587 Joules. The efficiency of this system is $90.35 \%$. The range of error in the Volt meter is $+-0.56 \%$, and the ampere meter is $+-2.19 \%$.

Key words : Solar panel, Synchronous Buck Converter, MPPT, VRL 


\section{PENDAHULUAN}

Berlimpahnya energi surya yang diterima wilayah Negara Indonesia, seharusnya dapat menjadi solusi untuk menggantikan sumber energi listrik konvensional seperti batu bara dan energi fosil lainnya menjadi energi terbarukan. Hingga tahun 2018 infrastruktur pembangkit listrik masih didominasi oleh pembangkit listrik tenaga uap dengan rasio sebesar 42.34\%, dengan pembangkitan terbesar berada di PLTU Paiton Probolinggo. Sedangkan rasio infrastruktur pembangkitan dengan menggunakan energi terbarukan berupa PLTS sebesar $0.09 \%$ pada tahun 2018. [1]

Panel surya dapat mengonversi energi matahari menjadi energi listrik. Kekurangan sumber energi dari matahari yaitu bergantung pada kondisi cuaca. Untuk mengatasi hal tersebut diterapkanlah teknik pelacakan titik daya maksimum atau Maximmum Power Point Tracking (MPPT). MPPT merupakan metode yang dapat digunakan untuk mengekstrak daya maksimum untuk mengoptimalkan produksi energi listrik. Untuk memaksimalkan daya keluaran panel surya juga membutuhkan operasi yang maksimum dari konverter DCDC sebagai penghubung antara panel surya dengan penyimpan daya atau beban yang akan diberikan. [2]

Dalam perancangan konverter hal yang perlu diperhatikan yaitu pemilihan komponen yang akan digunakan sehingga akan mengurangi power losses pada konverter dan akan meningkatkan efisiensi. Untuk sistem tenaga surya ini diperlukan perbaikan nilai efisiensi pada konverter agar baterai lebih sering menerima daya charging. [3]

Synchronous buck converter menghasilkan tegangan yang lebih rendah dari tegangan masukan dan dapat menghasilkan arus tinggi sambil meminimalkan kehilangan daya, dengan efisiensi yang cukup baik untuk mengubah tegangan dari panel surya yang sesuai untuk pengisian baterai. Synchronous buck converter terdiri dari dua MOSFET daya, induktor output dan kapasitor output. Topologi buck spesifik ini mendapatkan namanya dari metode kontrol dua kekuatan MOSFET kontrol on / off disinkronkan untuk memberikan tegangan output yang diatur dan untuk mencegah MOSFET menyala secara bersamaan. Baterai lead-acid sering digunakan untuk penyimpanan karena memiliki ketahanan terhadap siklus pengisian-pelepasan. [4] [5]

Pada perangkat semikonduktor terdapat kerugian konduksi, seperti pada dioda. Dioda pada Buck converter konvensional memiliki Forward Voltage sebesar 0,6 V, Hal itulah yang menyebabkan rugi daya secara berkelanjutan pada converter. Untuk mengatasi rugi daya tersebut dilakukan desain uang yang mana dioda diganti dengan Metal Oxide Semiconductor Field Effect Transistor (MOSFET). Desain baru yang dari converter tersebut sering dinamakan dengan Synchronous Buck Converter, karena kedua MOSFET bekerja secara bergantian dan berkelanjutan. [6] [7] [8]

\section{METODE PENELITIAN}

A. Desain sistem

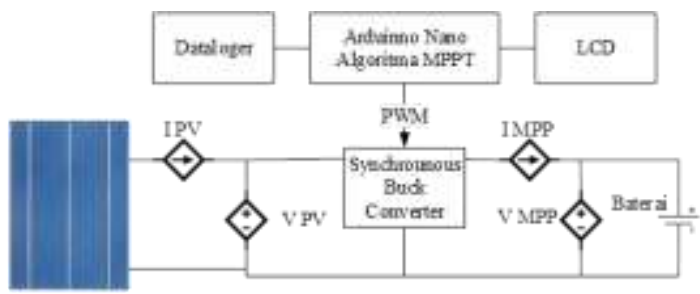

Gambar 1. Desain sistem secara keseluruhan

Diagram blok sistem kerja dari rancang bangun Synchronous Buck Converter pada panel surya menggunakan MPPT dengan beban baterai. Ketika panel surya mulai menerima foton dari sumber cahaya matahari, maka pada panel surya akan menghasilkan tegangan dan arus. Ketika muncul tegangan dan arus, maka akan dilakukan beberapa pengukuran pada keluaran panel surya, yaitu pengukuran tegangan menggunakan sensor tegangan, pengukuran arus dengan sensor arus ACS712 5 A. Pengukuran arus maupun tegangan ini akan digunakan untuk parameter masukan algoritma MPPT. Algoritma MPPT akan menentukan besar Duty Cycle (D) untuk mengontrol pensaklaran pada mosfet yang ada di Synchronous Buck Converter.

\section{B. Perancangan PV}

Panel surya yang digunakan dalam penelitian ini merupakan panel surya jenis polycrystalline dengan kapasitas $50 \mathrm{Wp}$. Berikut ini merupakan spesifikasi dari panel surya yang digunakan. 
Tabel 1. Spesifikasi panel surya

\begin{tabular}{|l|l|}
\hline \multicolumn{2}{|c|}{ Panel Surya Pollycrystalline 50Wp } \\
\hline Luas Permukaan & $0,3024 \mathrm{~m}^{2}$ \\
\hline Daya Maksimum (Pmax) & $50 \mathrm{Wp}$ \\
\hline Open Circuit Voltage (Voc) & $21,63 \mathrm{~V}$ \\
\hline Short Circuit Current (Isc) & $3,12 \mathrm{~A}$ \\
\hline Voltage at Pmax (Vmp) & $17,13 \mathrm{~V}$ \\
\hline Current at Pmax (Imp) & $2.92 \mathrm{~A}$ \\
\hline Test Condition & $1000 \mathrm{~W} / \mathrm{m}^{2}, 25^{\circ} \mathrm{C}$ \\
\hline Power Tolerance & $5 \%$ \\
\hline
\end{tabular}

C. Perancangan DC-DC Synchronous Buck Converter

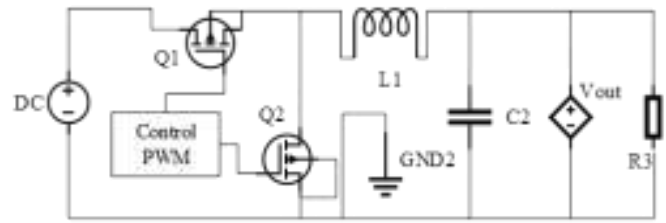

Gambar 2. Rangkaian Synchronous buck converter

Untuk mendesain DC-DC Synchronous buck converter diperlukan beberapa parameter utama, yaitu spesifikasi dari converter tersebut. Spesifikasi tersebut disesuaikan dengan spesifikasi dari panel surya dan spesifikasi beban yang akan digunakan.

Tabel 2. Spesifikasi panel surya

\begin{tabular}{|l|l|l|}
\hline \multicolumn{3}{|c|}{ Spesifikasi Synchronous buck converter } \\
\hline \multicolumn{1}{|c|}{ Parameter } & Simbol & \multicolumn{1}{c|}{ Target } \\
\hline Tegangan Masukan & Vin & 15 Volt \\
\hline Tegangan Nominal & Vout & 12 Volt \\
\hline Arus Keluaran maksimum & Imax & $4,2 \mathrm{~A}$ \\
\hline Frekuensi pensaklaran & fsw & $50 \mathrm{kHz}$ \\
\hline Riple tegangan & CVR & 0.02 \\
\hline Riple arus & LIR & 0,35 \\
\hline
\end{tabular}

Menentukan induktansi maksimum dan minimum, Untuk mendapat arus riak yang kurang lebih 35\% dari arus maksimal

$$
\begin{aligned}
& \Delta \mathrm{I}_{\mathrm{L}}=\mathrm{LIR} \times \mathrm{I}_{\mathrm{OUT}, \mathrm{MAX}} \\
& \Delta \mathrm{I}_{\mathrm{L}}=0.35 \times 4.2=1.47
\end{aligned}
$$

Setelah mendapatkan estimasi ripple arus maka untuk menghitung lout minimun sebagai berikut

$$
\begin{aligned}
& \mathrm{I}_{\text {OUT,MIN }}=\frac{\Delta \mathrm{I}_{\mathrm{L}}}{2} \\
& \mathrm{I}_{\mathrm{OUT}, \mathrm{MIN}}=\frac{1,47}{2}=0.735 \mathrm{~A}
\end{aligned}
$$

Maka arus riak induktor dapat didefinisikan sebagai berikut

$$
\begin{aligned}
& \mathrm{I}_{\mathrm{PK}}=\mathrm{I}_{\mathrm{OUT}, \mathrm{MAX}}+\frac{\Delta \mathrm{L}_{\mathrm{L}}}{2} \frac{0.35 \times 4.2}{2} \\
& \mathrm{I}_{\mathrm{PK}}=4.2+\frac{0.35 \times 4.2}{2}=4,935 \mathrm{~A}
\end{aligned}
$$

Pemilihan induktor dapat didefinisikan menjadi

$$
\begin{aligned}
& \mathrm{L}_{\text {MIN }} \frac{\left(V_{\text {IN }}-V_{\text {OUT }}\right) \times D}{L I R \times I_{\text {OUT,MAX }} \times f_{S W}} \\
& L_{\text {MIN }} \cong \frac{(15-12) \times 0.8}{0,35 \times 4,2 \times 50 \times 10^{3}} \cong 32,65 \mu \mathrm{H} \cong \pm 33 \mu \mathrm{H}
\end{aligned}
$$

Jadi nilai induktansi yang dibutuhkan untuk merancang Synchronous buck converter sebesar $33 \boldsymbol{\mu} \boldsymbol{H}$ dan 5 Ampere.

Pada pemilihan kapasitor ini digunakan estimasi ripple tegangannya adalah $5 \%$. Maka dapat dihitung ripple tegangan sebagai berikut.

$$
\begin{aligned}
& C_{\text {MIN }}=\frac{\text { LIR } \times \text { IOUT,MAX }}{8 \times x_{S W} \times C V R \times V_{\text {OUT }}} \\
& C_{\text {MIN }}=\frac{1,47}{8 \times 50000 \times 0.2}=183.75 \mu \mathrm{F}
\end{aligned}
$$

Dengan memeperhatikan rentang yang cukup pemilihan kapasitor dengan nilai sebesar $220 \mu \mathrm{F}$

Driver MOSFET memungkinkan sinyal keluaran digital arus rendah dari Mikrokontroler untuk menggerakkan gerbang MOSFET. Sinyal digital 5 volt dapat mengganti MOSFET tegangan tinggi menggunakan driver. Desain menggunakan driver setengah gelombang IC IR2104. IC mengambil sinyal PWM yang masuk dari Mikrokontroller, dan kemudian terdapat dua output untuk MOSFET Sisi Tinggi dan Rendah.

\section{Flowchart MPPT Perturb and Observe (P\&O)}

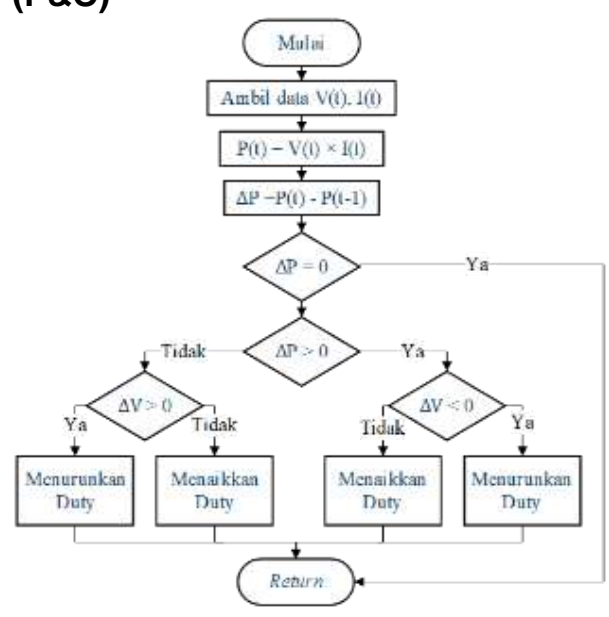

Gambar 3. Flowchart algoritma MPPT Perturb And Observe (P\&O) 
Teknik ini digunakan untuk menentukan dutycycle PWM yang akan dikirimkan ke DC-DC Synchronous buck converter. Untuk dapat melacak titik daya maksimum dari sistem maka dibutuhkan data tegangan keluaran converter dan arus keluaran yang mana dapat menentukan daya maksimum yang masuk pada baterai.

\section{E. Perencanaaan Baterai}

Penelitian ini menggunakan baterai dengan jenis VRLA (Valve Regulated Lead Acid) dengan kapasitas 12 Volt 12 Ah. Karena baterai VRLA ini merupakan salah satu jenis baterai yang tidak memerlukan perawatan khusus, sistem ini tidak membutuhkan arus pelepasan yang tinggi serta baterai dengan jenis industri mudah didapatkan.

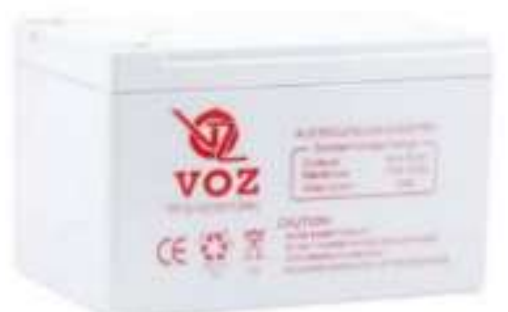

Gambar 4. Bentuk Fisik Baterai VRLA

\section{HASIL DAN PEMBAHASAN}

\section{A. Pengujian Karakteristik Panel Surya 50 WP}

Pengujian dilakukan dengan waktu pukul 08.00 WIB sampai dengan pukul 14.00 WIB. Didapatkan beberapa data sebagai berikut.

Tabel 3. Pengujian Karakteristik Panel Surya 50WP

\begin{tabular}{|c|l|c|c|c|c|c|}
\hline $\begin{array}{c}\text { Waktu } \\
\text { WIB }\end{array}$ & $\begin{array}{c}\text { Iradiansi } \\
\text { W/m2 }\end{array}$ & $\begin{array}{c}\text { Voc } \\
\text { (V) }\end{array}$ & $\begin{array}{c}\text { Isc } \\
\text { (A) }\end{array}$ & $\begin{array}{c}\text { Pin } \\
\text { (Watt) }\end{array}$ & $\begin{array}{c}\text { Pout } \\
\text { (Watt) }\end{array}$ & $\begin{array}{c}\mathbf{n} \\
(\%)\end{array}$ \\
\hline 08.00 & 384 & 19,42 & 1,22 & 116,12 & 17,56 & 15,12 \\
\hline 08.30 & 407 & 19,03 & 1,41 & 123,08 & 19,89 & 16,16 \\
\hline 09.00 & 512 & 19,14 & 1,59 & 154,83 & 22,56 & 14,57 \\
\hline 09.30 & 655 & 18,85 & 1,98 & 198,07 & 27,66 & 13,97 \\
\hline 10.00 & 695 & 19,19 & 2,35 & 210,17 & 33,43 & 15,90 \\
\hline 10.30 & 631 & 19,26 & 1,83 & 190,81 & 26,12 & 13,69 \\
\hline 11.00 & 771 & 19,44 & 2,67 & 233,15 & 38,47 & 16,50 \\
\hline 11.30 & 690 & 18,95 & 2,43 & 208,66 & 34,13 & 16,36 \\
\hline 12.00 & 820 & 19,31 & 2,78 & 247,97 & 39,79 & 16,05 \\
\hline 12.30 & 677 & 20,42 & 1,91 & 204,72 & 28,91 & 14,12 \\
\hline 13.00 & 489 & 19,25 & 1,75 & 147,87 & 24,97 & 16,89 \\
\hline 13.30 & 520 & 19,13 & 1,56 & 157,25 & 22,12 & 14,07 \\
\hline 14.00 & 425 & 19,71 & 1,42 & 128,52 & 20,74 & 16,14 \\
\hline
\end{tabular}

Daya keluaran panel surya didapatkan dari hasil perkalian antara nilai tegangan Voc, arus Isc dan Fill factor (FF). FF merupakan nilai rasio tengangan dan arus pada keadaan daya maksimal dan tengangan Voc dan arus Isc

Sedangkan Fill factor dapat ditulis sebagai berikut

$$
\mathrm{FF}=\frac{\mathrm{Vmax} \times 1 \mathrm{max}}{\mathrm{Voc} \times 1 \mathrm{sc}}
$$

\section{B. Pengujian Sensor tegangan}

Berikut adalah tabel pembacaan sensor tengangan dan pembacaan multimeter.

Tabel 4. Pengujian Sensor Tegangan Input

\begin{tabular}{|l|l|l|}
\hline $\begin{array}{c}\text { Sensor } \\
\text { Tegangan (V) }\end{array}$ & Multimeter (V) & Error (E\%) \\
\hline 12,41 & 12,48 & 0,56 \\
\hline 12,95 & 13,02 & 0,54 \\
\hline 13,77 & 13,85 & 0,58 \\
\hline 14,22 & 14,30 & 0,56 \\
\hline 15,13 & 15,22 & 0,59 \\
\hline 16,32 & 16,41 & 0,55 \\
\hline 17,19 & 17,29 & 0,58 \\
\hline 17,91 & 18,01 & 0,56 \\
\hline 18,14 & 18,24 & 0,55 \\
\hline 18,22 & 18,30 & 0,44 \\
\hline 19,51 & 19,62 & 0,56 \\
\hline 20,12 & 20,24 & 0,59 \\
\hline 21,53 & 21,65 & 0,55 \\
\hline 22,32 & 22,45 & 0,58 \\
\hline 23,45 & 23,59 & 0,59 \\
\hline Rata - Rata E\% & & $\mathbf{0 , 5 6 \%}$ \\
\hline
\end{tabular}

Dari Pengujian sensor tengangan dapat dibandingkan untuk mengetahui nilai error persen rata-rata yaitu sebesar $0,56 \%$.

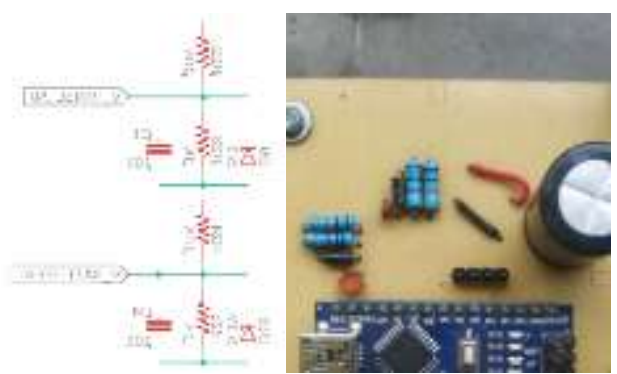

Gambar 5. Sensor Tegangan 


\section{Pengujian Sensor Arus}

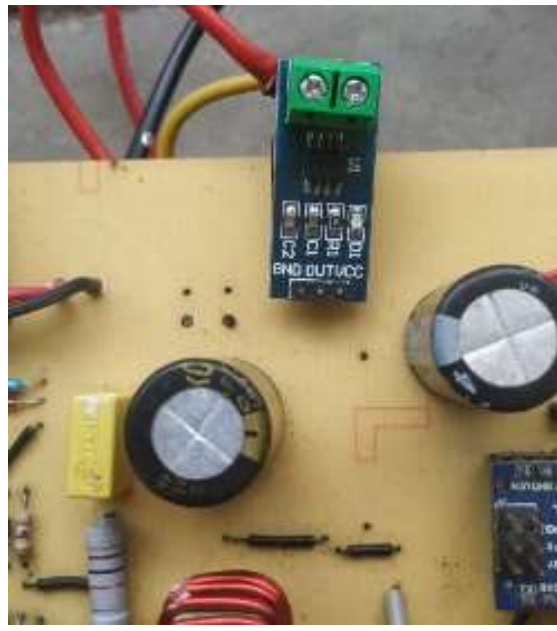

Gambar 6. Sensor ACS 712

Pengambilan data pengujian sensor arus bertujuan agar menghasilkan
pembacaan sensor yang diharapkan dapat lebih akurat.

Tabel 5. Hasil pengujian Arus

\begin{tabular}{|l|l|l|l|}
\hline No & $\begin{array}{c}\text { Sensor } \\
\text { ACS712 (A) }\end{array}$ & \multicolumn{1}{|c|}{$\begin{array}{c}\text { Multimeter } \\
\text { (A) }\end{array}$} & $\begin{array}{c}\text { Error } \\
\text { Persen } \\
\text { (E\%) }\end{array}$ \\
\hline 1 & 0,102 & 0,10 & 2,00 \\
\hline 2 & 0,205 & 0,20 & 2,50 \\
\hline 3 & 0,531 & 0,52 & 2,12 \\
\hline 4 & 0,910 & 0,89 & 2,25 \\
\hline 5 & 1,050 & 1,02 & 2,94 \\
\hline 6 & 1,170 & 1,14 & 2,63 \\
\hline 7 & 1,365 & 1,34 & 1,87 \\
\hline 8 & 1,480 & 1,45 & 2,07 \\
\hline 9 & 1,580 & 1,55 & 1,94 \\
\hline 10 & 1,840 & 1,80 & 2,22 \\
\hline 11 & 2,051 & 2,01 & 2,04 \\
\hline 12 & 2,350 & 2,30 & 2,17 \\
\hline 13 & 2,530 & 2,48 & 2,02 \\
\hline 14 & 2,675 & 2,62 & 2,10 \\
\hline 15 & 2,980 & 2,92 & 2,05 \\
\hline Rata - Rata E\% & & $\mathbf{2 , 1 9}$ \\
\hline
\end{tabular}

Dari Pengujian sensor arus dapat dibandingkan untuk mengetahui nilai error persen rata-rata yaitu sebesar $2,19 \%$.

\section{D, Analisis Pengujian sinyal PWM}

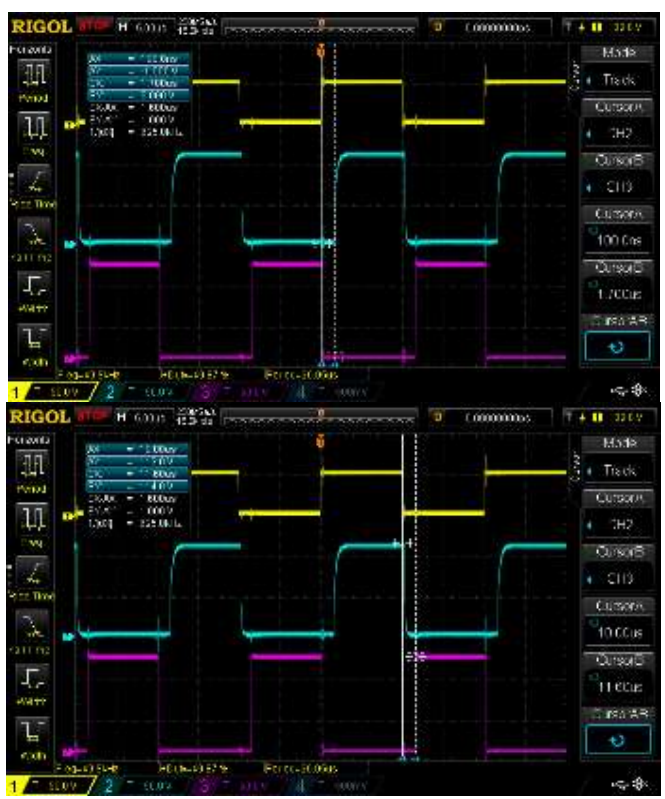

Gambar7.Sinyal PWM, untuk Gate 1, dan Gate 2

Pengujian dilakukan untuk mengetahui bentuk gelombang yang akan digunakan untuk switching converter. Sinyal dengan warna kuning merupakan generator PWM, Sinyal dengan warna biru merupakan Gate 1, Sinyal dengan warna ungu merupakan gate 2 , dimana setiap pergantian dari waktu hidup dan mati terdapat titik mati selama 1,6 us pada periode pensaklaran 20 us.

\section{E. Pengujian Baterai}

Pengujian ini dilakukan untuk mengetahui kondisi baterai serta mengondisikan isi baterai kurang lebih $10 \%$.

Tabel 6. Data hasil pengujian discharge batera

\begin{tabular}{|l|l|l|l|l|l|}
\hline No. & Menit & $\mathbf{V}(\mathbf{V})$ & $\mathbf{I}(\mathbf{A})$ & Watt & Ah \\
\hline 1 & 20 & 12,93 & 1,47 & 19,01 & 0,53 \\
\hline 2 & 40 & 12,84 & 1,46 & 18,75 & 0,52 \\
\hline 3 & 60 & 12,74 & 1,45 & 18,47 & 0,51 \\
\hline 4 & 80 & 12,65 & 1,44 & 18,22 & 0,51 \\
\hline 5 & 100 & 12,56 & 1,43 & 17,96 & 0,50 \\
\hline 6 & 120 & 12,46 & 1,42 & 17,69 & 0,49 \\
\hline 7 & 140 & 12,37 & 1,41 & 17,44 & 0,48 \\
\hline 8 & 160 & 12,28 & 1,4 & 17,19 & 0,48 \\
\hline 9 & 180 & 12,19 & 1,39 & 16,94 & 0,47 \\
\hline 10 & 200 & 12,1 & 1,38 & 16,70 & 0,46 \\
\hline 11 & 220 & 12,01 & 1,37 & 16,45 & 0,46 \\
\hline 12 & 240 & 11,92 & 1,35 & 16,09 & 0,45 \\
\hline 13 & 260 & 11,83 & 1,34 & 15,85 & 0,44 \\
\hline 14 & 280 & 11,74 & 1,33 & 15,61 & 0,43 \\
\hline 15 & 300 & 11,65 & 1,32 & 15,38 & 0,43 \\
\hline 16 & 320 & 11,56 & 1,31 & 15,14 & 0,42 \\
\hline 17 & 340 & 11,48 & 1,30 & 14,92 & 0,41 \\
\hline 18 & 360 & 11,39 & 1,28 & 14,58 & 0,40 \\
\hline 19 & 380 & 11,30 & 1,27 & 14,35 & 0,40 \\
\hline 20 & 400 & 11,22 & 1,26 & 14,14 & 0,39 \\
\hline 21 & 420 & 11,13 & 1,25 & 13,91 & 0,39 \\
\hline 22 & 440 & 11,05 & 1,23 & 13,59 & 0,38 \\
\hline 23 & 460 & 10,96 & 1,22 & 13,37 & 0,37 \\
\hline 24 & 480 & 10,88 & 1,21 & 13,16 & 0,37 \\
\hline Jumlah & & & $\mathbf{1 2 8 , 3 1}$ & $\mathbf{1 0 , 6 9}$ \\
\hline
\end{tabular}


Kapasitas nominal $=$ total discharge + $(10 \% \times 12 A h)=10,69+1,2 A h=$

11,81 Ah

\section{F. Pengujian konverter dengan beban}

Pengujian dilakukan dengan variasi perubahan duty cycle dengan rentang $10 \%$ hingga $90 \%$. Untuk mengetahui efisiensi ( $\eta$ ) dari konverter.

Tabel 7. Data pengujian konverter dengan beban $15 \mathrm{Ohm}$.

\begin{tabular}{|l|l|l|l|l|l|}
\hline $\mathbf{D}(\%)$ & \multicolumn{1}{|c|}{ Vin } & \multicolumn{1}{|c|}{ Vout } & \multicolumn{1}{|c|}{ lin } & lout & $\boldsymbol{n}(\%)$ \\
\hline 10 & 22,65 & 1,675 & 0,047 & 0,109 & 17,15 \\
\hline 20 & 22,64 & 3,899 & 0,097 & 0,255 & 45,27 \\
\hline 30 & 22,63 & 5,799 & 0,159 & 0,38 & 61,24 \\
\hline 40 & 22,62 & 7,92 & 0,251 & 0,52 & 72,54 \\
\hline 50 & 22,6 & 9,9 & 0,365 & 0,615 & 73,81 \\
\hline 60 & 22,58 & 12,1 & 0,501 & 0,8 & 85,57 \\
\hline 70 & 22,56 & 14,2 & 0,688 & 0,944 & 86,36 \\
\hline 80 & 22,52 & 16,4 & 0,898 & 1,094 & 88,72 \\
\hline 90 & 22,49 & 18,6 & 1,118 & 1,231 & 91,06 \\
\hline \multicolumn{7}{|l|}{ Rata-rata } & & $\mathbf{8 3 , 6 3}$ \\
\hline
\end{tabular}

Besarnya duty cycle yang masuk ke konverter menjadikan peningkatan besar daya yang keluar dari konverter atau masuk ke beban. Hal ini menjadikan besarnya duty cycle berbanding lurus dengan daya yang masuk ke beban.

\section{G. Analisis Algoritma MPPT P\&O}

Tabel 8. Hasil pengujian MPPT dengan algoritma $\mathrm{P} \& \mathrm{O}$ per 10 detik

\begin{tabular}{|c|c|c|c|c|c|c|}
\hline $\begin{array}{c}\text { Pukul } \\
\text { (WIB) }\end{array}$ & $\begin{array}{c}\text { Vin } \\
\text { (V) }\end{array}$ & $\begin{array}{c}\text { Vout } \\
\text { (V) }\end{array}$ & $\begin{array}{c}\text { lin } \\
(\mathbf{A})\end{array}$ & $\begin{array}{c}\text { lout } \\
(\mathbf{A})\end{array}$ & $\begin{array}{c}\mathbf{D} \\
\mathbf{( \% )}\end{array}$ & $\mathbf{n}(\%)$ \\
\hline 08.00 .10 & 15,12 & 12,35 & 0,39 & 0,45 & 92,78 & 93,83 \\
\hline 08.00 .20 & 16,22 & 12,37 & 0,33 & 0,37 & 75,25 & 84,29 \\
\hline 08.00 .30 & 17,03 & 12,20 & 0,33 & 0,37 & 74,52 & 80,52 \\
\hline 08.00 .40 & 19,87 & 12,28 & 0,49 & 0,54 & 79,87 & 68,65 \\
\hline 08.00 .50 & 16,51 & 12,40 & 0,54 & 0,58 & 85,90 & 79,52 \\
\hline 08.01 .00 & 17,64 & 12,42 & 0,93 & 0,98 & 86,36 & 72,41 \\
\hline 08.01 .10 & 18,64 & 12,15 & 0,93 & 1,03 & 89,27 & 71,80 \\
\hline 08.01 .20 & 19,28 & 12,19 & 0,64 & 0,80 & 75,30 & 78,80 \\
\hline 08.01 .30 & 19,22 & 12,08 & 0,63 & 0,78 & 75,22 & 78,02 \\
\hline 08.01 .40 & 19,18 & 12,10 & 0,71 & 0,85 & 76,99 & 75,20 \\
\hline
\end{tabular}

Data diatas diambil dari masukan converter dan keluaran converter yang mana untuk memastikan Algoritma MPPT P\&O yang disematkan pada Arduino bekerja sesuai dengan flowchart yang dibuat
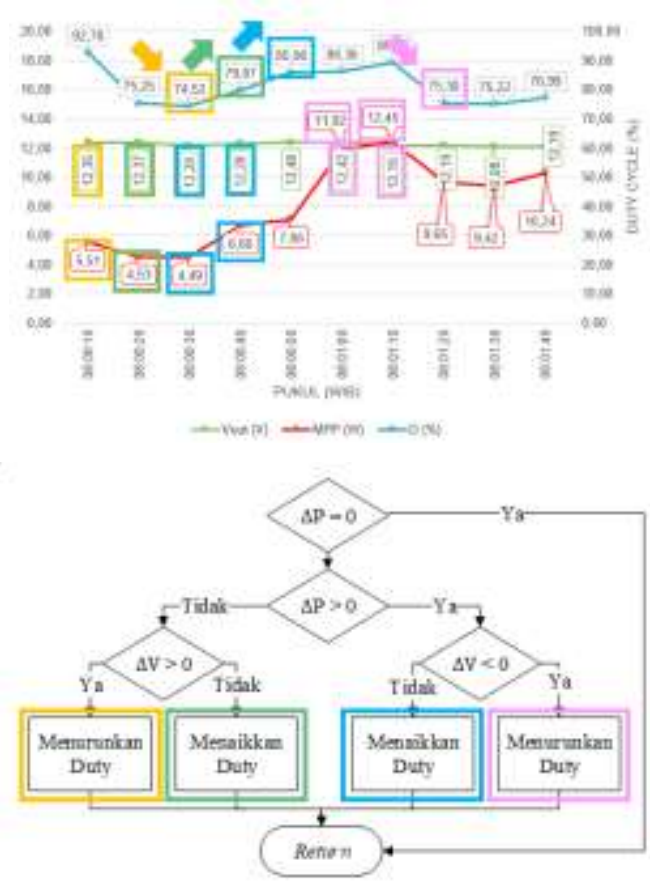

Gambar 8. Analisis Pelacakan daya sistem Panel surya

\section{H. Analisis Pengujian Sistem Secara} Keseluruhan.

Pengujian ini dilakukan pada tanggal 1 Mei 2020 dengan rentang waktu pukul 08.00 WIB sampai dengan 14.00 WIB di laboraturium Sistem Tenaga, Fakultas Teknik, Universitas Jember. Dengan mengabaikan kondisi cuaca untuk mengetahui kinerja dari keseluruhan sistem.

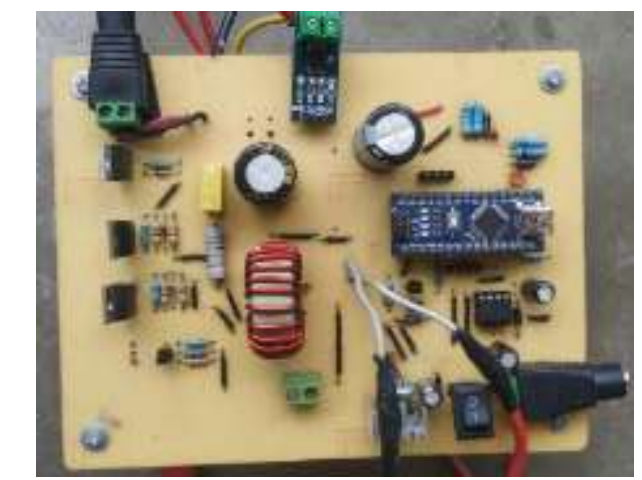

Gambar 9. Synchronous Buck Converter yang telah dibangun

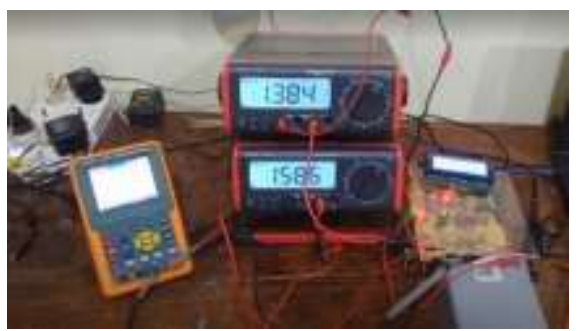

Gambar 10. pengujian sistem secara keseluruhan 
Berdasarkan dari hasil pengujian sistem secara keseluruhan dengan rentang waktu 6 jam maka dituliskan sebagai berikut. Dapat dihitung energi yang dihasilkan panel surya dengan persamaan berikut.

$$
\begin{aligned}
& E=\text { Rata-rata daya }(W) \times t(s) \\
& E=21,71 \times 21600=468845,0587 \text { Joule }
\end{aligned}
$$

Dalam satuan Wh (Watt hour) maka sebagai berikut.

$$
\begin{aligned}
& E(W h)=\frac{E}{3600} \\
& E(W h)=\frac{468845,0587}{3600}=130,235 W h
\end{aligned}
$$

Dalam satuan Ah (Ampere hour) maka sebagai berikut.

$\mathrm{Ah}=\frac{\mathrm{Wh}}{\text { Tegangan nominal }}$

$\mathrm{Ah}=\frac{130,235}{12}=10,8529 \mathrm{Ah}$

Dapat dihitung energi yang diterima oleh baterai atau keluaran dari konverter dengan persamaan berikut.

$E=19,61 \times 21600=423611,3807$ Joule

Dalam satuan Wh (Watt hour) maka sebagai berikut.

$\mathrm{E}(\mathrm{Wh})=\frac{423611,3807}{3600}=117,67 \mathrm{Wh}$

Dalam satuan Ah (Ampere hour) maka sebagai berikut.

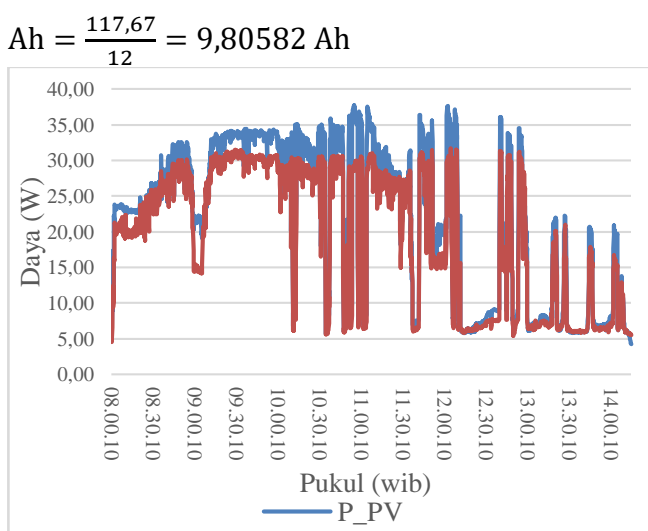

Gambar 11. Daya Pengujian Keseluhan.

Total energi yang dihasilkan panel surya yaitu sebesar 468845,0587 Joule atau 130,235 Wh sedangan total energi keluaran konverter sebesar 423611,3807 Joule atau 117,67 Wh. Total waktu untuk charge baterai 6 jam atau 360 menit. Semakin lama tegangan batterai semakin naik akan berbanding lurus dengan tegangan input maka didapatkan kapasitas nominal batterai saat charge menggunakan sistem sebesar 9,80582 Ah. Dengan nilai efisiensi rata-rata sebesar 90,35 \%. Daya yang dihasilkan panel surya rata-rata sebesar 21,71 Watt.

\section{KESIMPULAN}

Sistem kontrol MPPT menggunakan Synchronous Buck Conveerter yang dirancang mempunyai efisiensi tertinggi sebesar $99.92 \%$ dan efiesiensi terendah sebesar $65 \%$ dengan efisiensi rata-rata sebesar 90,35\%. Hasil rancang bangun Synchronous Buck Converter dengan kontrol MPPT panel surya Polycrystalline 50 WP pada penerapan sistem keseluruhan dengan durasi 6 jam atau 360 menit dapat mengisi baterai dengan total 9,80528 Ah.

\section{REFERENSI}

[1] Kementerian Energi dan Sumber Daya Mineral, Statistik Ketenagalistrikan 2018, Jakarta: Sekretariat Jenderal Ketenagalistrikan, 2019.

[2] B. Tito, "Metode MPPT Baru untuk Sel Surya Berdasarkan Pengendali PI," FT UI, 2012.

[3] F. H. Hasan, "Rancang Bangun Mppt Dengan DC-DC Buck Converter Pada Panel Surya Dengan Beban Pompa Air DC," FT Unej, 2017.

[4] S. S. I. Astra, "'Studi rancang bangun Solar Charge Controller dengan indikator arus"," Spektra: Jurnal Fisika dan Aplikasinya, vol. 11.

[5] U. I. D. C. H. M. Hasan, "Sistem Charging Baterai Pada Perancangan Mobil," Politeknik Negeri Surabaya.

[6] V. L. E. Taddy, "Modeling and simulation of a switch-mode synchronous buck," Politehnica University of Bucharest.

[7] A. Darmawansyah, "Analisis Dan Perancangan Integrated Circuit AND OR Invert (AOI)".

[8] Semiconductor Component Industries, "Selecsion Guide for the Synchronous Buck Converter," AND9135 